\title{
Changes in Religious Beliefs, Attitudes, and Practices Following Near-Death Experiences: An Australian Study
}

\author{
Cherie Sutherland, B.A. \\ University of New South Wales
}

\begin{abstract}
This study examined changes in religious beliefs, attitudes, and practices in the lives of 50 near-death experiencers. I attempted to clarify whether these changes were to greater religiousness or to a deeper spirituality. I found that before the near-death experience (NDE), my respondents were no more religious or spiritually inclined than the general Australian population. Following the NDE there was a statistically significant shift towards spirituality on most items investigated.
\end{abstract}

The near-death experience (NDE) is an intense, profoundly meaningful episode, following which many life changes are now known to occur. George Gallup Jr. (1982) reported that eight million Americans, or approximately five percent of the adult American population, have had what he called a "verge-of-death" or "temporary death" experience with some sort of mystical encounter associated with the actual death event. A recent Australian survey by Allan Kellehear and Patrick Heaven (1989) found that 10 percent of a sample of 173 people, when shown a vignette depicting five typical elements of an NDE, claimed to have had a similar experience. These figures are of considerable sociological significance.

Ms. Sutherland was formerly a lecturer in the Department of Social Work, University of Sydney, and is currently a full-time doctoral student in the School of Sociology, University of New South Wales. Reprint requests should be addressed to Ms. Sutherland at the School of Sociology, University of New South Wales, P.O. Box 1, Kensington, NSW 2033, Australia. 
This paper reports the results obtained from one section of a larger study still in progress, and concerns changes in religious beliefs, attitudes, and practices in the lives of 50 near-death experiencers (NDErs).

Most early studies of the NDE focused on the actual phenomenology of the experience itself. A few researchers have explored the connections between religion and NDEs from a variety of directions. David Royse (1985) conducted a questionnaire survey of 174 clergy to determine their attitudes and knowledge of NDEs. Michael Sabom (1982) made note not only of the religion but of the regularity of church attendance of each of the subjects in his medical investigation of NDEs. Carl Becker (1981) took a cross-cultural approach with an historical look at the centrality of NDEs to Chinese Pure Land Buddhism, and later explored the similarities between modern near-death accounts and both ancient Japanese deathbed visions (1984) and the theories of the Tibetan Bardo Thodol or Book of the Dead (1985).

Steven McLaughlin and Newton Maloney (1984) administered instruments to a sample of $40 \mathrm{NDErs}$ to measure religious orientation and religious change. As Kenneth Ring (1980) had earlier found, they detected no relationship between prior religiousness and depth of NDE. However, they did note an increase in importance of religion and religious activity. Ring (1980) and others have suggested that, although prior religiousness does not affect the occurrence or depth of NDEs, it can color their interpretation. This is particularly evident in Carol Zaleski's comparison of modern and medieval Christian neardeath accounts (1987) and in the findings of Craig Lundahl (1981-1982) concerning the perceived "other world" in Mormon NDEs.

In recent years, interest in the aftereffects of the NDE has grown. Ring (1984), Margot Grey (1985), Charles Flynn (1986), and P.M.H. Atwater (1988) all looked at a wide range of aftereffects, each giving some consideration to the question of religiousness of NDErs. They all concluded that experiencers became more religious after their NDEs, but it must be noted that this so-called religiousness was ambiguous in its manifestations. It tended more toward inward spiritual transformation rather than toward outward demonstrations of faith such as greater involvement in organized religion.

In the present study, I made a consistent effort to clarify this point. For example, in a question concerning the experience itself, I asked: "Would you describe your experience as a religious or spiritual experience or would you describe it in some other way?" In another question I asked: "Would you have described yourself as a religious or spiritual person before this experience? Now would you describe yourself as a religious or spiritual person?" As could have been suggested from the 
previous research cited, I found that my respondents in large numbers rejected the "religious" label, often vehemently, and availed themselves of the "spiritual" alternative, making clear the reason for their choice in most cases without any further prompting on my part.

Changes in belief following NDEs have also been explored by a number of researchers (Greyson and Stevenson, 1980; Grey, 1985; Flynn, 1986). For example, Sabom (1982) and Ring (1980) each found a dramatic increase in belief in an afterlife and a marked decrease in fear of death among their samples of NDErs. Sabom also found that religious views were often strengthened, although he noted that there was no change in religious affiliation (1982).

In order to determine whether my sample could be considered "normal" before their NDEs or whether they had already been unusually religious or spiritually inclined, I compared them with a sample from the general population. Although not all areas of my enquiry were covered, "The Australian Values Study Survey" (Roy Morgan Research Centre, 1983) provided some of the data on the religious and spiritual practices and associated beliefs among a general population appropriate for this comparison.

\section{Method}

Subjects for this study were located by various means. Since my interest centered on the aftereffects of the NDE rather than the experience itself, I interviewed only people who had had their experiences over two years ago. The 50 NDErs who were the subjects for this paper were contacted by various means:

1. 2 subjects responded to my published articles on the subject (Sutherland, 1987-1988, 1988);

2. 5 subjects responded to public talks I gave;

3. 2 subjects responded to media interviews;

4. 12 subjects were recruited from a sample of experiencers already obtained by another researcher; and

5. 29 subjects were referred to me by a third party who had read my articles, heard me speak, or met me in some other context.

I personally interviewed each of these 50 respondents, in semistructured interviews that usually lasted 90 minutes, although at times I spent much longer with them. These interviews dealt with a 
wide range of issues, of which their religious or spiritual practices and associated beliefs was only one.

The depth of NDE for each respondent was scored independently by myself and another person on the Weighted Core Experience Index (WCEI) developed by Ring (1980). This scale assigns a weighted score to each of 10 elements of the NDE. For example, a subjective sense of being dead is given 1 point, a clear out-of-body experience is given 4, and encountering visible "spirit" is given 3.

My interview included questions related to respondents' religion before and after the NDE; their perception of themselves as religious or spiritual before and since the NDE; their perception of the experience as religious or spiritual; nine religious or spiritual activities and associated beliefs both before and after the NDE; respondents' attitudes to suicide before and after the NDE; and the most significant change since the NDE.

A chi-squared test, which gives the probability that there has been no change since the NDE, was then performed on most of these items. I also made comparisons with the general population wherever possible, to determine whether my sample, before their NDEs, was "normal" or already unusually religious or spiritually inclined.

\section{Results}

The 50 respondents included 15 men and 35 women. Their ages at the time of the NDE ranged from 7 to 76 years. Twenty percent were 19 years old or younger, 58 percent were 20 to 39 years, 20 percent were 40 to 59 years, and 2 percent were 60 to 79 years. The number of years since their experience ranged from 2 to 52 .

The NDEs in this sample occurred as a result of illness in 17 cases; surgery or postoperative complications in 9 cases; pregnancy, miscarriage, or childbirth in 11 cases; serious injury in 7 cases; drowning in 2 cases; poisoning in 1 case; and suicide in 3 cases.

WCEI scores ranged from 6 to 24 , with a mean of $13.86 ; 17$ were "moderate" experiences scoring between 6 and 10, and 33 were "deep" experiences scoring 11 to 24 .

The religious denominations of NDErs before and after the NDE are summarized in Table 1, along with a comparison with the general population in Australia. Unlike Sabom (1982), I found a dramatic change in religious affiliation, especially from organized religion, of whatever denomination, to no religion. Only two respondents changed 
Table 1

Religious Denomination Before and after NDE

\begin{tabular}{lccc}
\hline & $\begin{array}{c}\text { Percent } \\
\text { General } \\
\text { Population }\end{array}$ & $\begin{array}{c}\text { Percent } \\
\text { Sample }(n=50) \\
\text { Before NDE }\end{array}$ & $\begin{array}{c}\text { Percent } \\
\text { Sample }(n=50) \\
\text { After NDE }\end{array}$ \\
\hline No religion & 16 & 46 & 84 \\
Curch of England & 28 & 24 & 4 \\
Roman Catholic & 26 & 12 & 8 \\
Methodist & 4 & 4 & 0 \\
Presbyterian & 7 & 2 & 0 \\
Jewish & $<$ & 2 & 0 \\
Baptist & 2 & 2 & 0 \\
Lutheran & 1 & 2 & 0 \\
Calvinist & no data & 2 & 0 \\
Brethren & no data & 4 & 2 \\
Buddhist & $<1$ & 0 & 2 \\
\hline
\end{tabular}

from no religion, one to Buddhism and the other to Roman Catholicism.

Of the general Australian population, 58 percent describe themselves as religious. Among my respondents, 24 percent stated they would have described themselves as religious before the NDE, 16 percent as spiritual, and 60 percent as neither. Following the NDE, 6 percent of my respondents described themselves as religious, 76 percent as spiritual, and 18 percent as neither.

None of my respondents perceived the NDE as a religious experience. However, 70 percent perceived it as a spiritual experience, 2 percent perceived it as both religious and spiritual, and 28 perceived it as neither religious nor spiritual.

The percentage of subjects who responded positively to questions concerning each of the nine religious or spiritual activities and associated beliefs before and after the NDE is summarized in Table 2, along with comparisons wherever possible with the general population. The number of subjects is less than $\mathbf{5 0}$ for some items, because I eliminated from analysis those respondents who could not remember or had not heard of or thought about various practices, phenomena, or beliefs before the NDE. This applied primarily to those who had had an NDE during childhood.

The attitudes of NDErs to suicide both before and since the NDE are summarized in Table 3 . I asked this question in a very general form 


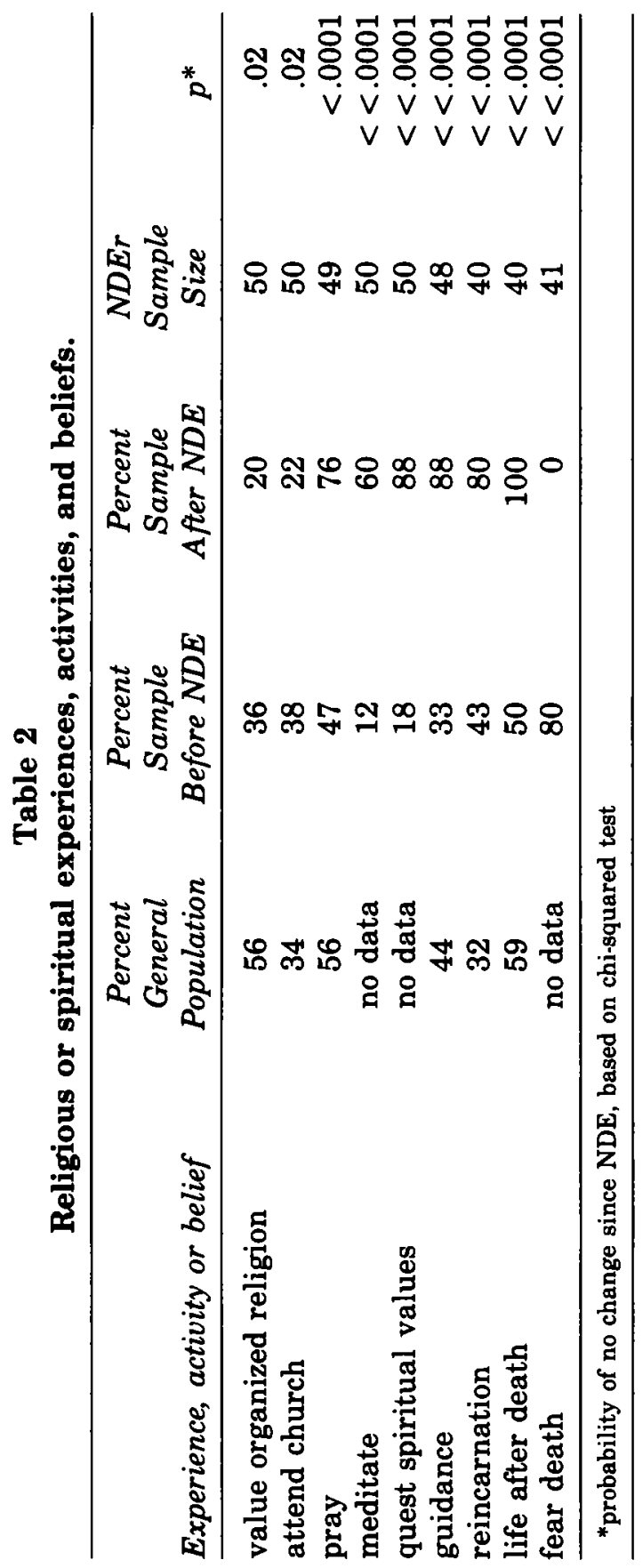




\section{Table 3}

Attitudes toward suicide

\begin{tabular}{lcc}
\hline $\begin{array}{l}\text { Attitude toward one's own suicide } \\
\text { or toward another person } \\
\text { committing suicide }\end{array}$ & $\begin{array}{c}\text { Percent } \\
\text { Sample }(n=50) \\
\text { Before NDE }\end{array}$ & $\begin{array}{c}\text { Percent } \\
\text { Sample }(n=50) \\
\text { After } N D E\end{array}$ \\
\hline tried it & 12 & 0 \\
thought of it & 30 & 0 \\
could do it if life purpose & & \\
$\quad$ achieved & 0 & 2 \\
self-righteous & 2 & 0 \\
feel compassion, sadness & 2 & 0 \\
no thoughts about it & 9 & 5 \\
wouldn't judge & 7 & 14 \\
no point in it & 0 & 9 \\
wrong to do it & 21 & 14 \\
wouldn't do it & 16 & 37 \\
\hline
\end{tabular}

that permitted respondents to answer in terms of attitudes either toward themselves committing suicide or toward others committing suicide.

Responses to my question about respondents' judgment of the most significant change to come about as a result of the NDE were as follows:

1. spirituality or spiritual growth, 31 percent of respondents;

2. love, 11 percent;

3. knowing God, 9 percent;

4. inner peace, 9 percent;

5. more responsible, caring, 7 percent;

6. no fear of death, 7 percent;

7. deepened beliefs, 4 percent;

8. life of service, 4 percent;

9. self-understanding, 4 percent;

10. no fear, 2 percent;

11. thirst for knowledge, 2 percent;

12. greater awareness, 2 percent;

13. open attitude, 2 percent;

14. able to feel, 2 percent; and

15. not introverted, 2 percent. 


\section{Discussion}

About half of the sample claimed to have had no religious affiliation at the time of the NDE, while after the NDE 84 percent claimed to have no religion.

Sixty percent claimed to be neither religious nor spiritual in orientation before the NDE. Since their WCEI scores ranged from 6 to 24, this confirms Ring's finding that prior religiousness has no apparent bearing on either occurrence or depth of NDE. The remaining 40 percent were made up of those who claimed to have been religious (24 percent) and spiritual (16 percent) before the NDE. After the NDE, only 6 percent claimed to be still religious, while 76 percent now claimed to be spiritually inclined.

Over two-thirds perceived the NDE itself to be a spiritual experience, but 28 percent perceived it to be neither religious nor spiritual. Of those who perceived it to be a spiritual experience, over three-quarters had a WCEI score between 11 and 24, which suggests that the deeper the experience, the more likely it is that it will be perceived as spiritual in content.

The data in Table 2 concerning changes in activities, experiences, and beliefs after the NDE show an established shift on all nine items away from organized religion and church attendance and towards private informal prayer, meditation, and a general quest for spiritual values.

Of the 11 respondents who still attend church after the NDE, one person goes only to take her massively brain-damaged son, who enjoys the service. She stated that she can't accept the sermons being preached:

They say if you're not a Christian none of you will be able to come in through the eye of the needle, and all that sort of thing. And I think, well, I went up there and I saw it and I certainly wasn't a Christian at the time. So how do they know? So I can't accept it. I've got my own beliefs and I try to live my way.

Another of those 11 respondents enjoys going to church but claims she is a believer rather than a Roman Catholic and that her beliefs are not necessarily those of the Catholic Church. After describing her strong belief in reincarnation she laughed and said: "The Roman Catholic Church would be horrified if they knew what I believed."

A few others who attend church regularly, although nominally attached to a particular denomination, are happy in any church. One woman said: 
I feel that church is a bit of a sham. Not God but the people. They seem to fuss over stupid little things that are really just political. But I belong to a lot of churches. I play the guitar in the Roman Catholic folk group, I'm in the musical group of the Church of Christ, and I play with the Salvation Army. I'm probably Anglican but it doesn't worry me where I am-it's all God inside me.

With regard to belief in reincarnation and in life after death, as I noted elsewhere (Sutherland, 1989) the numbers tend to obscure the actual complexity of these beliefs. Those 41 percent who believed in reincarnation before the NDE believed in it only "a bit," whereas the 78 percent who believed in it afterwards tended to be more convinced. Similarly, the 50 percent who said they believed in life after death before the NDE generally retained such beliefs from their childhood religious training. On the other hand, 100 percent of my respondents now believe in life after death, and base that belief on their own experience, which in many cases explicitly contradicts the views held earlier.

Over three-quarters of my respondents said that they had a fear of death before the NDE, whereas not one person among my sample has a fear of death now. Many laughed at the question.

There is good agreement, within statistical errors, between the general population and my respondents' reports of their belief in the value of organized religion, their church attendance, their tendency to pray, their having a sense of being guided, and their belief in reincarnation and life after death before the NDE.

In terms of religious affiliation, my sample superficially appears to differ from the general population, in that 46 percent of them claimed to have had no religious affiliation prior to the NDE, compared to 16 percent of the general population. However, two-thirds of this group mentioned that they had had some religious training as children in a variety of denominations but had abandoned that before the NDE. They further volunteered that, had they been asked prior to the NDE about religion in a survey, they would normally have named a denomination just out of habit, although they were no longer affiliated with one. Therefore, although the 46 percent figure is accurate for my sample, it is not necessarily in disagreement with the Australian Values Survey results.

In terms of whether NDErs perceive themselves to have been religious or spiritual before the NDE, there also appears to be a discrepancy between my sample, 24 percent of whom considered themselves to have been religious, and the general population, 58 percent of whom 
regard themselves as religious. However, for the purpose of comparison with this general population figure, it is necessary to combine both "religious" (24 percent) and "spiritual" (16 percent) categories, due to the wording of the Australian Values Survey question. Thus, while the Australian Values Survey results can provide a basis for direct comparison on some items, for others a comparison should only be seen as suggestive, due to differences in methodology and in question wording.

My data also show a dramatic change in attitudes toward suicide. For my sample before the NDE, the sum of the "wouldn't do it" and "wrong to do it" categories is comparable to the 48 percent of the general population who believe suicide is never justified. Three of my respondents had their NDEs as a result of a suicide attempt; three others had attempted suicide at some other point in their lives; and 15 others had thought of suicide at some stage. However, since the NDE only one person out of 43 said that she could do it, and that was only if her life purpose was achieved.

Although it is sometimes suggested that people who have had NDEs or know about them would be more likely to take their own lives in order to re-enter the bliss of the "world of light," the above results demonstrate that the opposite is the case. People who have had NDEs do not take their own lives, and my data support recent studies that indicate that even repeated suicide attempters, once they have had an NDE, do not generally attempt to take their lives again (Greyson, 1981, 1986).

My final question concerned the most significant change to come about as a result of the NDE. As the list of responses above shows clearly, spiritual growth, a loving attitude, knowing God, and inner peace characterize the changes most meaningful to a majority of NDErs.

Overall, there is a feeling among my sample that they now have an ongoing direct contact with God or a Higher Power that requires no mediation by institutions such as a church or interpretation by the teachings of any denomination or tradition. If one was to assess many of the above results in isolation from the more distinguishing details of this particular population, one would have a group of people among whom 84 percent claim to have no religion, 80 percent see no value in organized religion, 78 percent never attend any church, and only 6 percent claim to be religious. It would be tempting to see this as further evidence of the secularization of our society. I believe this interpretation would be a mistake, and in fact this study calls into question just who is included in figures that are given as evidence of the pervasive Godlessness of our times. 


\section{References}

Atwater, P.M.H. (1988). Coming back to life New York, NY: Dodd, Mead.

Becker, C.B. (1981). The centrality of near-death experiences in Chinese Pure Land Buddhism. Anabiosis: The Journal of Near-Death Studies, 1, 154-171.

Becker, C.B. (1984). The Pure Land revisited: Sino-Japanese meditations and near-death experiences of the next world. Anabiosis: The Journal of Near-Death Studies, 4, 51-68.

Becker, C.B. (1985). Views from Tibet: Near-death experiences and the Book of the Dead. Anabiosis: The Journal of Near-Death Studies, 5, 3-20.

Flynn, C.P. (1986). After the beyond: Human transformation and the near-death experience. Englewood Cliffs, NJ: Prentice-Hall.

Gallup, G., Jr. (1982). Adventures in immortality: A look beyond the threshold of death. New York, NY: McGraw-Hill.

Grey, M. (1985). Return from death: An exploration of the near-death experience. London, England: Arkana.

Greyson, B. (1981). Near-death experiences and attempted suicide. Suicide and LifeThreatening Behavior, 11, 10-16.

Greyson, B. (1986). Incidence of near-death experiences following attempted suicide. Suicide and Life-Threatening Behavior, 16, 40-45.

Greyson, B., and Stevenson, I. (1980). The phenomenology of near-death experiences. American Journal of Psychiatry, 137, 1193-1196.

Kellehear, A., and Heaven, P. (1989). Community attitudes toward near-death experiences: An Australian study. Journal of Near-Death Studies, 7, 165-172.

Lundahl, C.R. (1981-1982). The perceived other world in Mormon near-death experiences: A social and physical description. Omega, 12, 319-327.

McLaughlin, S.A., and Maloney, H.N. (1984). Near-death experiences and religion: A further investigation. Journal of Religion and Health, 23, 149-159.

Ring, K. (1980). Life at death: A scientific investigation of the near-death experience. New York, NY: Coward, McCann and Geoghegan.

Ring, K. (1984). Heading toward omega: In search of the meaning of the near-death experience. New York, NY: William Morrow.

Roy Morgan Research Centre (1983). Australian values study survey (machine-readable data file.) Melbourne, Australia: Australian Values Study Steering Committee (Producer). Canberra, Australia: Social Science Data Archives, The Australian National University (Distributor).

Royse, D. (1985). The near-death experience: A survey of clergy's attitudes and knowledge. Journal of Pastoral Care, 39, 31-42.

Sabom, M.B. (1982). Recollections of death: A medical investigation. New York, NY: Harper and Row.

Sutherland, C. (1987-1988). A reflection of the near-death experience. Australian Journal of Transpersonal Psychology, 7, 118-134.

Sutherland, C. (1988). The near-death experience: Claiming life for the first time. Pallicom, 8(2), 18-23.

Sutherland, C. (1989). Psychic phenomena following near-death experiences: An Australian study. Journal of Near-Death Studies, 8, 93-102.

Zaleski, C. (1987). Otherworld journeys: Accounts of near-death experience in medieval and modern times. New York, NY: Oxford University Press. 